Vol 1. No. 4, Oktober 2021 P-ISSN : 2774-8030, e-ISSN : 2774-8030

\title{
PENERAPAN METODE MIND MAPPING UNTUK MENINGKATKAN HASIL BELAJAR MENULIS TEKS REPORT SISWA KELAS IX E SMP NEGERI 2 BEBANDEM SEMESTER I TAHUN PELAJARAN 2017/2018
}

\author{
IDA BAGUS PUTRA AGUNG
}

SMP Negeri 2 Bebandem

Email : putraagung240481@gmail.com

\begin{abstract}
ABSTRAK
Penelitian ini bertujuan untuk meningkatkan kemampuan menulis teks Report pada siswa kelas IX E semester I SMP Negeri 2 Bebandem Tahun Pelajaran 2017/2018. Penelitian ini adalah Penelitian Tindakan Kelas (PTK) yang dilaksanakan dalam dua siklus. Subjek penelitian adalah siswa kelas IX E SMP 2 Bebandem tahun pelajaran 2017/2018, sebanyak 22 orang. Pengumpulan data penelitian ini dilakukan dengan penilaian hasil kerja. Data hasil belajar dikumpulkan melalui lembar instrument. Data itu dianalisis dengan teknik deskriptifkuantitatif. Hasil yang diperoleh dari penelitian ini adalah penerapan metode Mind Mapping dapat meningkatkan hasil belajar siswa dalam menulis teks Report. Ini terbukti dari hasil yang diperoleh dipaparkan seperti berikut ini: Jumlah siswa yang memperoleh nilai di bawah Kriteria Ketuntasan Minimal (KKM). pada pelaksanaan Pra Siklus adalah 14 orang siswa pada, Siklus I menurun menjadi 5 orang siswa dan Siklus II hanya 4 orang siswa mendapat nilai di bawah Kriteria Ketuntasan Minimal (KKM). Nilai rata-rata kelas pada pelaksanaan Pra Siklus adalah 69,77 naik menjadi 78,63 pada Siklus I dan pada Siklus II naik menjadi 81,59. Tingkat ketuntasan belajar pada pelaksanaan Pra Siklus adalah siswa yang tuntas hanya 8 orang siswa atau $36,36 \%$, sedangkan pada Siklus I menjadi lebih banyak yaitu 17 orang siswa atau 78,63\% dan pada Siklus II meningkat menjadi 18 orang siswa atau $81,59 \%$. Berdasarkan hasil penelitian tersebut dapat disimpulkan bahwa penerapan metode Mind Mapping dapat meningkatkan hasil belajar siswa dalam menulis teks Report pada siswa kelas IX E SMP Negeri 2 Bebandem semester I tahun pelajaran 2017/2018.
\end{abstract}

Kata Kunci: metode Mind Mapping, hasil belajar.

\section{PENDAHULUAN}

Proses belajar-mengajar dilakukan siswa dan guru di sekolah. Siswa mendapatkan ilmu pengetahuan dari guru dalam proses belajar-mengajar. Kegiatan Belajar Mengajar (KBM) merupakan kegiatan yang menuntut guru berperan penuh dalam menentukan perkembangan anak. Guru bertugas membimbing dan memfasilitasi siswa dalam kegiatan belajar. Witherington (dalam Usman dan Setiawati, 2001: 5) menyatakan bahwa "Belajar adalah suatu proses perubahan di dalam kepribadian yang menyatakan diri sebagai suatu pola baru dari reaksi berupa kecakapan, sikap, kebiasaan kepribadian atau suatu pengertian”. Selanjutnya, Gagne (dalam Slameto, 2010: 13) memberikan dua definisi belajar, yakni: (1) belajar adalah suatu proses untuk memperoleh motivasi dalam pengetahuan, keterampilan, kebiasaan, dan tingkah laku; dan (2) belajar adalah penguasaan pengetahuan atau keterampilan yang diperoleh dari instruksi.

Dalam pengajaran atau proses belajar-mengajar guru memegang peran sebagai sutradara sekaligus aktor. Artinya, guru yang betugas dan bertanggung jawab merencanakan dan melaksanakan pengajaran di sekolah. Guru sebagai tenaga profesional harus memiliki sejumlah kemampuan mengaplikasikan berbagai teori belajar dalam bidang pengajaran, kemampuan memilih dan menerapkan metode pengajaran yang efektif dan efisien, kemampuan melibatkan siswa berpartisipasi aktif, dan kemampuan membuat suasana belajar yang menunjang tercapainya tujuan pendidikan

Faktor utama yang paling menentukan meningkatnya mutu akademik siswa adalah pengelolaan kegiatan belajar mengajar oleh guru. Dalam proses belajar mengajar diharapkan untuk membina pola pikir, keterampilan, kebiasaan yang terbuka dan bertanggung jawab, 
mampu menyesuaikan diri secara manusiawi terhadap perubahan di segala bidang termasuk kehidupan manusia. Mengajar tidak hanya sekedar pengalihan pengetahuan dan keterampilan. Mengajar harus mampu membina kemahiran peserta didik untuk kreatif, dapat menghadapi segala situasi. Setiap usaha mengajar bertujuan untuk menumbuhkan atau menyempurnakan pola tingkah laku tertentu dari siswa, yaitu sejumlah kegiatan yang lazim dilakukan manusia untuk bertahan hidup dan untuk memperbaiki hidupnya.

Guru sebagai komunikator diharapkan dapat menggunakan bahasa yang baik dan mudah dimengerti, terutama dalam penyampaian materi pelajaran. Siswa tidak akan mungkin bisa memahami bahan pembelajaran yang disampaikan guru apabila guru dalam penyampaiannya tidak menggunakan bahasa yang komunikatif. Guru harus dapat mempersiapkan diri baik dari segi penguasaan materi maupun keterampilan berbicara dan mempunyai pengetahuan dan pengalaman yang luas. Kondisi seperti ini akan dapat membantu siswa dalam memahami mata pelajaran yang disampaikan. Siswa akan lebih berkreatif untuk menciptakan ide-ide baru.

Guru bukan hanya berperan dalam mengembangkan pengetahuan dan keterampilan saja. Mereka juga berfungsi meningkatkan keterampilan menulis serta menumbuhkan budaya menulis di kalangan siswa. Untuk meningkatkan kreativitas siswa, guru harus dapat menumbuhkan rasa ingin tahu alamiah, memotivasi, menumbuhkan percaya diri dan memancing siswa untuk mengekspresikan bentuk kreativitasnya dalam bentuk nyata.

Ada empat aspek keterampilan berbahasa, yaitu membaca, menyimak, berbicara, dan menulis. Di antara keempat keterampilan tersebut, yang dianggap paling membutuhkan penguasaan keterampilan paling tinggi adalah keterampilan berbahasa dalam bidang menulis. Keterampilan menulis dibutuhkan banyak aspek antara lain penguasaan kosakata sebagai faktor intrinsik yang mendukung keterampilan menulis.

Menulis merupakan keterampilan seseorang dalam mengekspresikan pikiran dan perasaan yang disampaikan melalui bahasa tulis yang realisasinya berupa simbol-simbol grafis sehingga orang lain, yaitu pembaca mampu memahami pesan yang terkandung di dalamnya. Menulis merupakan kegiatan yang produktif dan ekspresif sehingga keterampilan ini tidak datang dengan sendirinya akan tetapi membutuhkan latihan dan kebiasaan yang berkesinambungan.

Menulis dapat dianggap sebagai suatu proses maupun suatu hasil. Menulis merupakan kegiatan yang dilakukan oleh seseorang untuk menghasilkan sebuah tulisan. Menurut Heaton dalam St. Y. Slamet (2008:141) menulis merupakan keterampilan yang sukar dan kompleks. Atar Semi (2007:14) dalam bukunya mengungkapkan pengertian menulis adalah suatu proses kreatif memindahkan gagasan ke dalam lambang-lambang tulisan. Burhan Nurgiantoro (1988: 273) menyatakan bahwa menulis adalah aktivitas aktif produktif, yaitu aktivitas menghasilkan bahasa.

Menurut (Suparno dan Yunus, 2008: 1.3), Menulis dapat didefinisikan sebagai "Suatu kegiatan penyampaian pesan (komunikasi) dengan menggunakan bahasa tulis sebagai alat medianya". Tarigan (2008: 22), menyatakan, menulis adalah menemukan atau melukiskan lambang-lambang grafik yang menggambarkan suatu bahasa yang dipahami oleh seseorang sehingga orang lain dapat membaca lambang-lambang grafik tersebut kalau mereka memahami bahasa dan gambaran grafik itu.

Menurut Byrne dalam Slamet (2007: 141), mengungkapkan bahwa keterampilan menulis pada hakikatnya bukan sekedar kemampuan menulis simbol-simbol grafis sehingga berbentuk kata, dan kata-kata dapat disusun menjadi kalimat menurut peraturan tertentu, melainkan keterampilan menulis adalah kemampuan menuangkan buah pikiran ke dalam bahasa tulis melalui kalimat-kalimat yang dirangkai secara utuh, lengkap, dan jelas sehingga buah pikiran tersebut dapat dikomunikasikan kepada pembaca dengan berhasil.

Berdasarkan pendapat tersebut di atas, dapat disimpulkan menulis merupakan kegiatan berupa penuangan ide/gagasan dengan kemampuan yang kompleks melalui aktivitas yang aktif 
produktif dalam bentuk simbol huruf dan angka secara sistematis sehingga dapat dipahami oleh orang lain.

Keterampilan menulis bagi banyak orang bukanlah suatu hal yang mudah dan menyenangkan, termasuk bagi para siswa baik siswa SD, SMP, ataupun SMA. Seseorang yang tidak terbiasa menulis akan mengalami kesulitan ketika harus menuangkan gagasan dalam bentuk tertulis. Sebaliknya, seseorang yang sudah terbiasa menuangkan ide atau peristiwa yang dialaminya dalam bentuk tertulis, seperti biasa menulis buku harian, maka akan mudah baginya untuk menulis. Faktor yang membantu seseorang agar mudah menulis bukan hanya karena terbiasa menulis, namun juga karena kegemarannya membaca. Dengan membaca, seseorang akan mendapatkan informasi ataupun pengetahuan dan kosa kata yang variatif.

Semua pemaparan diatas berbanding lurus dengan kenyataan di lapangan yang dialami oleh peneliti. Hasil uji kemampuan menulis pada saat diadakan ulangan harian (Pra Siklus) dengan materi teks Report di kelas IX E hasilnya sangat rendah. Hasil dari perumusan Kriteria Ketuntasan Minimal (KKM) mata pelajaran Bahasa Inggris di Sekolah Menegah Pertama Negeri 2 Bebandem kelas IX adalah 79. Pada saat diadakan ulangan harian (Pra Siklus) hanya 6 orang siswa dari 22 siswa di kelas tersebut yang memperoleh nilai di atas Kriteria Ketuntasan Minimal (KKM). Ini berarti ketuntasan belajar di kelas tersebut hanya 36,36\%, dengan kata lain masih ada 16 orang siswa yang memperolah nilai dibawah Kriteria Ketuntasan Minimal (KKM).

Setelah mengamati uraian diatas, dapat dilihat sebuah gambaran belum berhasilnya hasil dan proses belajar. Ini merupakan masalah yang harus segera diatasi. Sebagai upaya memperbaiki kegagalan tersebut, penulis berusaha mencari metode pembelajaran yang tepat sebagai solusi selanjutnya. Penulis sadar bahwa di era Kurikulum Satuan Tingkat Pendidikan (KTSP) ini, guru dituntut untuk kreatif dan inovatif. Guru harus mampu menerapkan metode pembelajaran yang sesuai dengan situasi dan kondisi kelas. Prinsip PAIKEM (Pembelajaran Aktif, Inovatif, Kreatif, Efektif dan Menyenangkan) harus dilaksanakan. Guru bukan lagi merupakan sosok yang ditakuti dan bukan pula sosok otoriter, tetapi guru harus menjadi seorang fasilitator dan motor yang mampu memfasilitasi dan menggerakkan siswanya untuk mendapatkan ilmu yang mereka butuhkan.

Setelah mengikuti pelatihan guru dalam penyusunan laporan Penelitian Tindakan Kelas (PTK) yang diselengarakan Musyawarahh Guru Mata Pelajaran (MGMP) Bahasa Inggris kemudian setelah membaca beberapa buku tentang metode pembelajaran dan penelitian yang terkait dengan masalah yang dialami penulis, maka penulis menetapkan metode Mind Mapping untuk diterapkan dalam meningkatkan hasil belajar siswa menulis teks Report. Metode Mind Mapping dapat memudahkan siswa dalam mencari ide untuk menulis dan membantu siswa menulis agar tidak bingung dalam merangkai kata-kata tulisan. Dengan metode Mind Mapping siswa dapat memetakan terlebih dahulu ide-ide yang siswa miliki dan kemudian siswa dapat menyusnnya dengan kata-kata baik. Selain itu juga siswa akan lebih berminat untuk menulis teks Report karena dengan menggunakan metode ini siswa akan mudah untuk menulis teks Report dan dapat pula menggunakan gambar dan warna.

\section{METODE PENELITIAN}

Metode tes adalah cara pengumpulan data yang menghadapkan sejumlah pertanyaanpertanyaan atau suruhan-suruhan kepada subyek penelitian, Budiyono (2003:54). Metode tes pada penelitian ini yaitu pengambilan data pada setiap akhir siklus atau akhir penyajian mata pelajaran. Bentuk tes yang digunakan adalah tes tulis.

Penelitian tindakan kelas ini dilaksanakan di SMP Negeri 2 Bebandem, yang berlokasi di Jalan Raya Bebandem - Budakeling, Kecamatan Bebandem, Kabupaten Karangasem, Provinsi Bali. Dimana sekolah ini berada dilingkungan yang mayoritas penduduknya berprofesi sebagai pengerajin berbagai macam peralatan kerja yang berbahan dasar dari besi, seperti pisau, kapak, sabit, cangkul dan berbagai macam peralatan berbahan dasar besi yang lainnya. SMP Negeri 2 Bebandem, memiliki halaman yang sangat luas. Berbagai jenis tanaman perindang tumbuh 
dengan subur di sekolah ini. Sehingga udara segar dan suasana sejuk menjadi sesuatu yang tidak asing lagi jika berada di sekolah ini. Kelebihan lain dari sekolah ini adalah lokasinya yang berada dijalur yang jumlah kendaraaannya yang melintas tidak terlalu ramai. Jadi untuk melakukan proses belajar mengajar sangat sesuai sekali.

\section{HASIL DAN PEMBAHASAN}

\section{Pra Siklus}

Kondisi awal hasil nilai ulangan (Pra Siklus) yang dilakukan oleh guru sebelum penelitian, menunjukkan sebagian besar nilai siswa $(63,63 \%)$ tidak tuntas. Sedangkan range nilai terendah 45 dan tertinggi 85, menunjukkan kesenjangan nilai yang besar. Berikut ini daftar hasil belajar siswa pada pelaksanaan Pra Siklus:

Tabel 1. Nilai Ketuntasan Hasil Belajar Siswa Menulis Teks Report

\begin{tabular}{|c|c|c|c|c|}
\hline No & NIS & Kode Peserta Didik & Nilai & Keterangan \\
\hline 1 & 5432 & E 001 & 85 & Tuntas \\
\hline 2 & 5433 & E 002 & 85 & Tuntas \\
\hline 3 & 5434 & E 003 & 85 & Tuntas \\
\hline 4 & 5435 & E 004 & 85 & Tuntas \\
\hline 5 & 5436 & E 005 & 80 & Tuntas \\
\hline 6 & 5437 & E 006 & 80 & Tuntas \\
\hline 7 & 5438 & E 007 & 80 & Tuntas \\
\hline 8 & 5439 & E 008 & 80 & Tuntas \\
\hline 9 & 5440 & E 009 & 75 & Tidak Tuntas \\
\hline 10 & 5441 & E 010 & 70 & Tidak Tuntas \\
\hline 11 & 5442 & E 011 & 70 & Tidak Tuntas \\
\hline 12 & 5443 & E 012 & 70 & Tidak Tuntas \\
\hline 13 & 5444 & E 013 & 70 & Tidak Tuntas \\
\hline 14 & 5445 & E 014 & 65 & Tidak Tuntas \\
\hline 15 & 5446 & E 015 & 65 & Tidak Tuntas \\
\hline 16 & 5447 & E 016 & 65 & Tidak Tuntas \\
\hline 17 & 5448 & E 017 & 65 & Tidak Tuntas \\
\hline 18 & 5449 & E 018 & 65 & Tidak Tuntas \\
\hline 19 & 5450 & E 019 & 55 & Tidak Tuntas \\
\hline 20 & 5451 & E 020 & 50 & Tidak Tuntas \\
\hline 21 & 5452 & E 021 & 45 & Tidak Tuntas \\
\hline 22 & 5237 & E 022 & 45 & Tidak Tuntas \\
\hline \multicolumn{4}{|c|}{ JUMLAH NILAI } & 1535 \\
\hline \multicolumn{4}{|c|}{ RATA - RATA NILAI } & 69,77 \\
\hline \multicolumn{4}{|c|}{ DAYA SERAP } & 69,77 \\
\hline \multicolumn{4}{|c|}{ KETUNTASAN BELAJAR } & $36,36 \%$ \\
\hline \multicolumn{4}{|c|}{ KRITERIA KETUNTASAN MINIMAL (KKM) } & 79 \\
\hline
\end{tabular}

Tabel 2. Nilai Ketuntasan Hasil Belajar Siswa Menulis Teks Report

\begin{tabular}{|c|c|c|c|}
\hline $\begin{array}{c}\text { Kriteria } \\
\begin{array}{c}\text { Ketuntasan Minimal } \\
\text { (KKM) 79 }\end{array}\end{array}$ & $\begin{array}{c}\text { Frekuensi } \\
\text { (Siswa) }\end{array}$ & $\begin{array}{c}\text { Presentase } \\
(\mathbf{\%})\end{array}$ & Keterangan \\
\hline$<79$ & 14 & $63,63 \%$ & Tidak Tuntas \\
\hline$\geq 79$ & 8 & $36,36 \%$ & Tuntas \\
\hline Jumlah Nilai & \multicolumn{2}{|c|}{$\mathbf{~}$} \\
\cline { 1 - 3 }
\end{tabular}




\begin{tabular}{|l|c|}
\hline Rata - Rata & $\mathbf{6 9 , 7 7}$ \\
\hline Nilai Tertinggi & $\mathbf{8 5}$ \\
\hline Nilai Terendah & $\mathbf{4 5}$ \\
\hline
\end{tabular}

Jika nilai ketuntasan hasil belajar menulis teks Report siswa kelas IX E Sekolah Menengah Pertama Negeri 2 Bebandem pada pelaksanaan Pra Siklus disajikan dalam bentuk diagram maka akan terlihat seperti berikut:

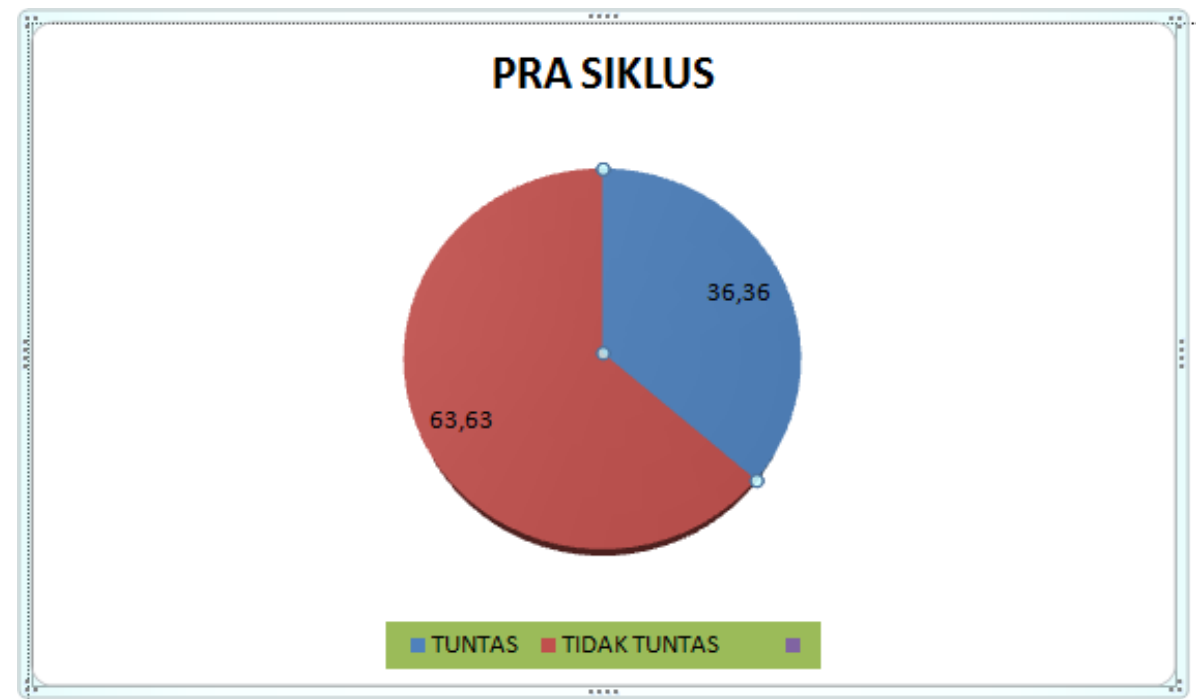

Gambar 1. Nilai Ketuntasan Hasil Belajar Menulis Teks Report

Metode pembelajaran yang dilakukan guru menggunakan metode ceramah. Terlihat beberapa siswa kurang bersemangat mengikuti pembelajaran Bahasa Inggris. Suasana pembelajaran berlangsung dengan kaku dan beberapa siswa diam. Hal ini tampak dari muka siswa yang diam, mengerutkan alis mata dan tanpa ada pertanyaan dari siswa ke guru. Ini mencerminkan kondisi siswa yang kurang santai selama mengikuti pembelajaran Bahasa Inggris, sehingga mata pelajaran Bahasa Inggris mengakibatkan hasil belajar siswa menjadi rendah. Hal ini dimungkinkan dengan metode ceramah, sebagian besar konsentrasi belajar siswa kurang fokus pada pelajaran Bahasa Inggris.

Siswa mengeluh dalam mengikuti pelajaran Bahasa Inggris yang dirasa membosankan, membingungkan dan tidak menarik. Terutama bila siswa dihadapkan dengan materi menulis, maka sebagian siswa mengalami kesulitan. Siswa kurang memiliki ide dan gagasan tentang apa yang akan ditulis. Berdasarkan data nilai hasil belajar siswa kelas IX E dalam menulis teks Report masih rendah, sehingga permasalahan tersebut harus diatasi agar tidak berdampak pada bagian lain dalam pendidikan khususnya pembelajaran di sekolah.

Rendahnya nilai hasil belajar siswa kelas IX E dalam menulis teks Report dipengaruhi oleh belum terarah dan terorganir degan baik ide dan gagasan yang akan dituangkan dalam bentuk tulisan. Penggunaan metode konvensional (ceramah satu arah) secara terus menerus akan terasa monoton yang mengakibatkan pembelajaran kurang menarik bagi siswa. Siswa merasa jenuh dan pasif selama pembelajaran. Transformasi ilmupun terjadi kurang maksimal, karena pembelajaran berpusat pada guru sehingga pembelajaran menjadi kurang efektif.

\section{Siklus I}

Sementara nilai hasil belajar siswa kelas IX E dalam menulis teks Report pada pelaksanaan Siklus I dapat dilihat pada hasil belajar siswa seperti berikut ini: 
Vol 1. No. 4, Oktober 2021 P-ISSN : 2774-8030, e-ISSN : 2774-8030

\begin{tabular}{|c|c|c|c|c|}
\hline No & NIS & Kode Peserta Didik & Nilai & Keterangan \\
\hline 1 & 5432 & E 001 & 85 & Tuntas \\
\hline 2 & 5433 & E 002 & 85 & Tuntas \\
\hline 3 & 5434 & E 003 & 85 & Tuntas \\
\hline 4 & 5435 & E 004 & 85 & Tuntas \\
\hline 5 & 5436 & E 005 & 85 & Tuntas \\
\hline 6 & 5437 & E 006 & 85 & Tuntas \\
\hline 7 & 5438 & E 007 & 85 & Tuntas \\
\hline 8 & 5439 & E 008 & 80 & Tuntas \\
\hline 9 & 5440 & E 009 & 80 & Tuntas \\
\hline 10 & 5441 & E 010 & 80 & Tuntas \\
\hline 11 & 5442 & E 011 & 80 & Tuntas \\
\hline 12 & 5443 & E 012 & 80 & Tuntas \\
\hline 13 & 5444 & E 013 & 80 & Tuntas \\
\hline 14 & 5445 & E 014 & 80 & Tuntas \\
\hline 15 & 5446 & E 015 & 80 & Tuntas \\
\hline 16 & 5447 & E 016 & 80 & Tuntas \\
\hline 17 & 5448 & E 017 & 80 & Tuntas \\
\hline 18 & 5449 & E 018 & 70 & Tidak Tuntas \\
\hline 19 & 5450 & E 019 & 70 & Tidak Tuntas \\
\hline 20 & 5451 & E 020 & 65 & Tidak Tuntas \\
\hline 21 & 5452 & E 021 & 65 & Tidak Tuntas \\
\hline 22 & 5237 & E 022 & 65 & Tidak Tuntas \\
\hline \multicolumn{4}{|c|}{ JUMLAH NILAI } & 1730 \\
\hline \multicolumn{4}{|c|}{ RATA - RATA NILAI } & 78,63 \\
\hline \multicolumn{4}{|c|}{ DAYA SERAP } & $78,63 \%$ \\
\hline \multicolumn{4}{|c|}{ KETUNTASAN BELAJAR } & 77,27 \\
\hline \multicolumn{4}{|c|}{ KRITERIA KETUNTASAN MINIMAL (KKM) } & 79 \\
\hline
\end{tabular}

Tabel 2. Nilai Ketuntasan Hasil Belajar Siswa Menulis Teks Report Siklus I

\begin{tabular}{|c|c|c|c|}
\hline $\begin{array}{c}\text { Kriteria } \\
\text { Ketuntasan Minimal } \\
(\mathrm{KKM}) 79\end{array}$ & $\begin{array}{c}\text { Frekuensi } \\
\text { (Siswa) }\end{array}$ & $\begin{array}{c}\text { Presentase } \\
(\%)\end{array}$ & Keterangan \\
\hline$<79$ & 5 & $22,72 \%$ & Tidak Tuntas \\
\hline$\geq 79$ & 17 & $77,27 \%$ & Tuntas \\
\hline Jumlah Nilai & \multicolumn{2}{|c|}{1730} & \\
\hline Rata - Rata & \multicolumn{2}{|c|}{78,63} & \\
\hline Nilai Tertinggi & \multicolumn{2}{|c|}{85} & \\
\hline Nilai Terendah & \multicolumn{2}{|c|}{65} & \\
\hline
\end{tabular}




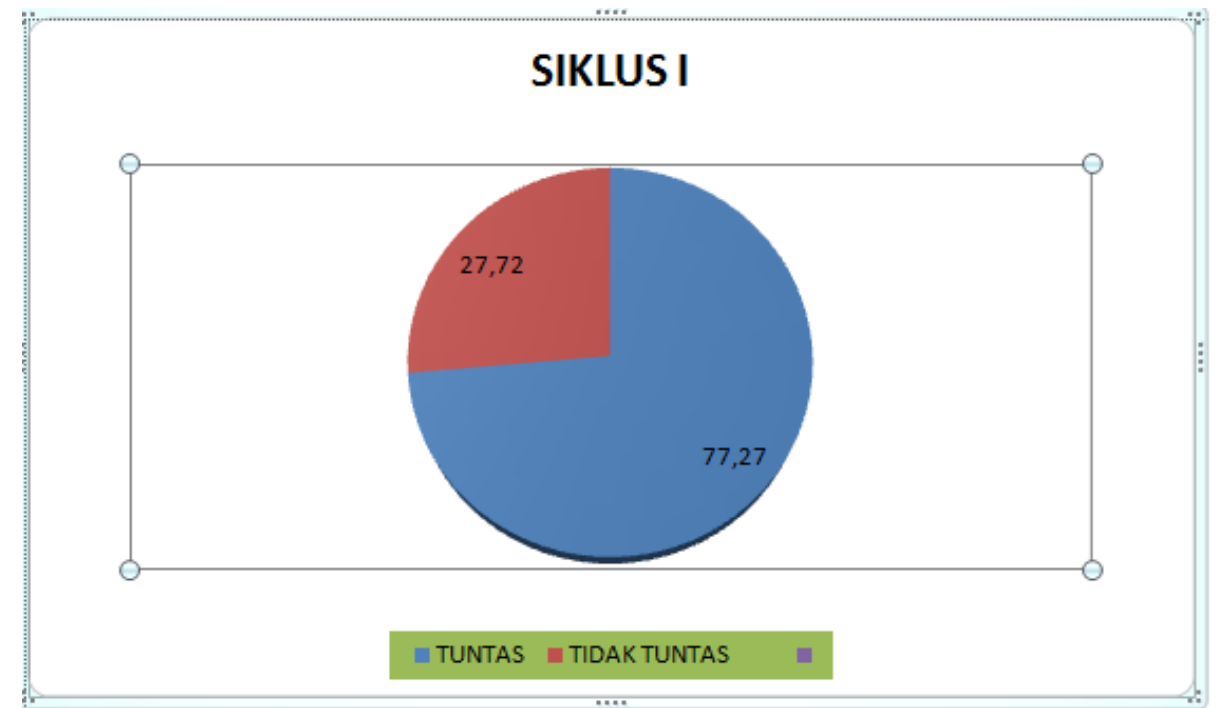

Gambar 2. Nilai Ketuntasan Hasil Belajar Menulis Teks Report Siklus I

Berdasarkan data di atas diketahui bahwa pelaksanaan pembelajaran Siklus I menunjukkan ada peningkatan hasil belajar siswa. Sebanyak 17 orang siswa $(77,27 \%)$ dinyatakan tuntas belajar karena memperoleh nilai di atas Kriteria Ketunasan Minimal (KKM) $(\geq 79)$. Sedangkan siswa yang tidak tuntas sebanyak 5 orang (22,72\%). Artinya sebanyak 9 orang siswa $(40,90 \%)$ dapat ditingkatkan nilai hasil belajarnya. Ini menunjukkan siswa mampu menulis teks Report. Dengan demikian penerapan metode Mind Mapping berpengaruh terhadap peningkatan hasil belajar siswa.

\section{Siklus II}

Hasil belajar pada pelaksanaan Siklus II adalah sebagai berikut:

Tabel 5. Nilai Ketuntasan Hasil Belajar Siswa Menulis Teks Report Siklus II

\begin{tabular}{|c|c|c|c|c|}
\hline No & NIS & Kode Peserta Didik & Nilai & Keterangan \\
\hline 1 & 5432 & E 001 & 95 & Tuntas \\
\hline 2 & 5433 & E 002 & 95 & Tuntas \\
\hline 3 & 5434 & E 003 & 85 & Tuntas \\
\hline 4 & 5435 & E 004 & 85 & Tuntas \\
\hline 5 & 5436 & E 005 & 85 & Tuntas \\
\hline 6 & 5437 & E 006 & 85 & Tuntas \\
\hline 7 & 5438 & E 007 & 85 & Tuntas \\
\hline 8 & 5439 & E 008 & 80 & Tuntas \\
\hline 9 & 5440 & E 009 & 80 & Tuntas \\
\hline 10 & 5441 & E 010 & 80 & Tuntas \\
\hline 11 & 5442 & E 011 & 80 & Tuntas \\
\hline 12 & 5443 & E 012 & 80 & Tuntas \\
\hline 13 & 5444 & E 013 & 80 & Tuntas \\
\hline 14 & 5445 & E 014 & 80 & Tuntas \\
\hline 15 & 5446 & E 015 & 80 & Tuntas \\
\hline 16 & 5447 & E 016 & 80 & Tuntas \\
\hline 17 & 5448 & E 017 & 80 & Tuntas \\
\hline 18 & 5449 & E 018 & 80 & Tuntas \\
\hline 19 & 5450 & E 019 & 75 & Tidak Tuntas \\
\hline 20 & 5451 & E 020 & 75 & Tidak Tuntas \\
\hline 21 & 5452 & E 021 & 75 & Tidak Tuntas \\
\hline
\end{tabular}


Vol 1. No. 4, Oktober 2021 P-ISSN : 2774-8030, e-ISSN : 2774-8030

\begin{tabular}{|l|c|c|}
\hline $22 \quad 5237$ & 75 & Tidak Tuntas \\
\hline JUMLAH NILAI E 022 & $\mathbf{1 7 9 5}$ \\
\hline RATA - RATA NILAI & $\mathbf{8 1 , 5 9}$ \\
\hline DAYA SERAP & $\mathbf{8 1 , 5 9 \%}$ \\
\hline KETUNTASAN BELAJAR & $\mathbf{8 1 , 8 1 \%}$ \\
\hline KRITERIA KETUNTASAN MINIMAL (KKM) & $\mathbf{7 9}$ \\
\hline
\end{tabular}

Tabel 6. Nilai Ketuntasan Hasil Belajar Siswa Menulis Teks Report Siklus II

\begin{tabular}{|c|c|c|c|}
\hline $\begin{array}{c}\text { Kriteria } \\
\text { Ketuntasan Minimal } \\
(\text { KKM) } 79\end{array}$ & $\begin{array}{c}\text { Frekuensi } \\
\text { (Siswa) }\end{array}$ & $\begin{array}{c}\text { Presentase } \\
(\%)\end{array}$ & Keterangan \\
\hline$<79$ & 4 & $18,18 \%$ & Tidak Tuntas \\
\hline$\geq 79$ & 18 & $81,81 \%$ & Tuntas \\
\hline Jumlah Nilai & \multicolumn{2}{|c|}{1795} & \\
\hline Rata - Rata & \multicolumn{2}{|c|}{81,59} & \\
\hline Nilai Tertinggi & \multicolumn{2}{|c|}{95} & \\
\hline Nilai Terendah & \multicolumn{2}{|c|}{75} & \\
\hline
\end{tabular}

\section{SIKLUS II}

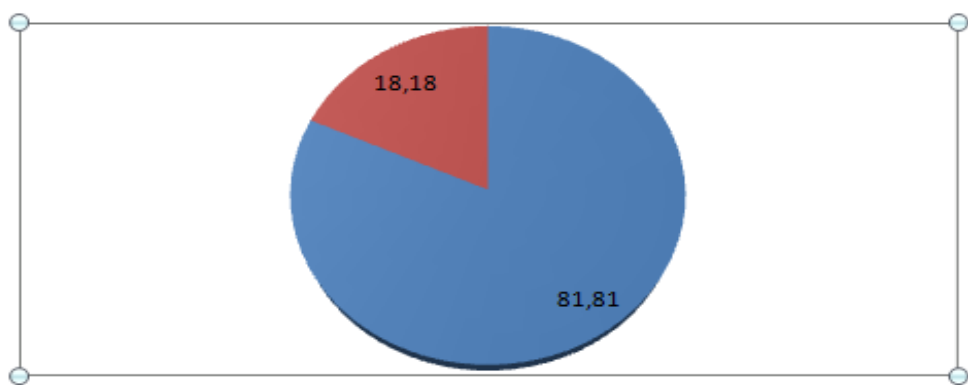

TUNTAS $=$ TIDAK TUNTAS

Gambar 3 Nilai Ketuntasan Hasil Belajar Menulis Teks Report Siklus II

Berdasarkan data di atas diketahui bahwa pelaksanaan pembelajaran Siklus II terjadi peningkatan hasil belajar siswa. Jumlah siswa yang tuntas sebanyak 18 orang siswa $(81,81 \%)$. Dari Siklus I ke Siklus II terjadi peningkatan siswa yang tuntas dari 17 orang menjadi 18 orang. Sebanyak 4 orang siswa yang mana keempat orang siswa tersebut berjenis kelamin laki - laki, dinyatakan tidak tuntas belajar karena memperoleh nilai di bawah Kriteria Ketunasan Minimal (KKM) (<79). Pada Siklus II telah mengalami perubahan dibandingkan pada Siklus I, yaitu terjadi peningkatan nilai rata-rata siswa. Pada siklus II nilai terendah 80 dengan nilai rata-rata siswa mencapai 81,59 dan nilai tertinggi 95 .

Dari hasil pengamatan diketahui, bahwa sebanyak 4 orang siswa pada siklus II tetap tidak mencapai ketuntasan atau nilainya tetap di bawah Kriteria Ketunasan Minimal (KKM) $(<79)$.

Perbandingan Nilai Ketuntasan Hasil Belajar pada Pra Siklus, Siklus I dan Siklus II

Perbandingan ketuntasan hasil belajar siswa pada tiap tahapan disajikan dalam tabel 4 berikut. 
Vol 1. No. 4, Oktober 2021 P-ISSN : 2774-8030, e-ISSN : 2774-8030

Tabel 7. Perbandingan Nilai Ketuntasan Belajar Siswa Pada Pra Siklus, Siklus I dan Siklus II

\begin{tabular}{|c|c|c|c|c|c|c|c|c|}
\hline \multirow[b]{2}{*}{$\begin{array}{l}\mathrm{N} \\
\mathrm{o}\end{array}$} & \multirow[b]{2}{*}{$\begin{array}{c}\text { Nilai } \\
\text { KKM } \\
79\end{array}$} & \multicolumn{2}{|c|}{ Pra Siklus } & \multicolumn{2}{|c|}{ Siklus I } & \multicolumn{2}{|c|}{ Siklus II } & \multirow[b]{2}{*}{ Keterangan } \\
\hline & & $\begin{array}{c}\text { Jumla } \\
\text { h } \\
\text { Siswa } \\
\end{array}$ & $\begin{array}{c}\text { Persenta } \\
\text { se } \\
(\%)\end{array}$ & $\begin{array}{c}\text { Jumlah } \\
\text { Siswa }\end{array}$ & $\begin{array}{c}\text { Persentas } \\
\mathrm{e} \\
(\%)\end{array}$ & $\begin{array}{c}\text { Jumla } \\
\text { h } \\
\text { Siswa }\end{array}$ & $\begin{array}{c}\text { Persentas } \\
\mathrm{e} \\
(\%)\end{array}$ & \\
\hline 1. & $<79$ & 14 & $63,63 \%$ & 5 & $22,72 \%$ & 4 & $18,18 \%$ & $\begin{array}{l}\text { Tidak } \\
\text { Tuntas }\end{array}$ \\
\hline 2. & $\geq 79$ & 8 & $36,36 \%$ & 17 & $77,27 \%$ & 18 & $81,81 \%$ & Tuntas \\
\hline \multicolumn{2}{|c|}{ Jumlah } & \multicolumn{2}{|c|}{1535} & \multicolumn{2}{|c|}{1730} & \multicolumn{2}{|c|}{1795} & \\
\hline \multicolumn{2}{|c|}{ Rata-rata } & \multicolumn{2}{|c|}{ 69,77 } & \multicolumn{2}{|c|}{78,63} & \multicolumn{2}{|c|}{81,59} & \\
\hline \multicolumn{2}{|c|}{$\begin{array}{l}\text { Nilai } \\
\text { Tertinggi }\end{array}$} & \multicolumn{2}{|c|}{85} & \multicolumn{2}{|c|}{85} & \multicolumn{2}{|c|}{95} & \\
\hline \multicolumn{2}{|c|}{$\begin{array}{l}\text { Nilai } \\
\text { Terendah }\end{array}$} & \multicolumn{2}{|c|}{45} & \multicolumn{2}{|c|}{65} & \multicolumn{2}{|c|}{75} & \\
\hline
\end{tabular}

Pencapaian hasil belajar 22 orang siswa pada Pra Siklus, Siklus I dan Siklus II disajikan dalam diagram batang di bawah ini.

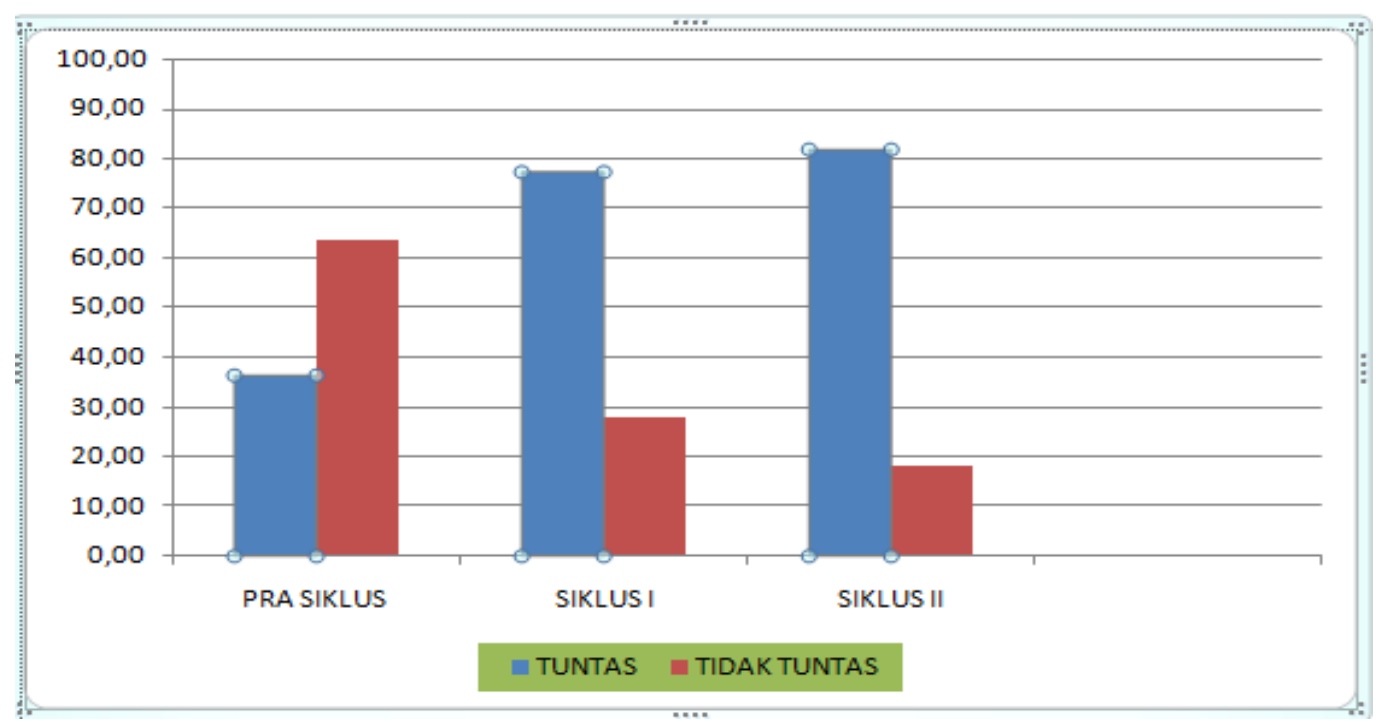

\section{Gambar 4. Perbandingan Nilai Ketuntasan Belajar Siswa Pada Pra Siklus, Siklus I dan Siklus II}

Dari diagram di atas terlihat bahwa jumlah ketuntasan nilai hasil belajar siswa meningkat, walaupun pada Siklus I dan Siklus II masih ada siswa yang berada di bawah Kriteria Ketuntasan Minimal (KKM). Peningkatan nilai terutama pada siswa yang pada tahap Pra Siklus berada di bawah Kriteria Ketuntasan Minimal (KKM). Bahkan ada siswa yang semula mendapatkan nilai 45 dapat meningkat mencapai nilai 65 di Siklus I dan 75 pada tes Siklus II. Hal ini membuktikan bahwa metode Mind Mapping mampu meningkatkan hasil belajar siswa dalam menulis teks Report.

Berdasarkan hasil penelitian, maka secara keseluruhan metode Mind Mapping berpengaruh (signifikan) terhadap peningkatan hasil belajar siswa pada mata pelajaran Bahasa Inggris khususnya dalam menulis teks Report. Penelitian tindakan ini difokuskan pada upaya perbaikan untuk meningkatkan nilai ketuntasan hasil belajar Bahasa Inggris kelas IX E Sekolah Menengah Pertama Negeri 2 Bebandem. Metode Mind Mapping mengarahkan siswa untuk menuangkan ide dan gagasannya secara lebih terarah.

Pada pelaksanaan pembelajaran Siklus I, ada peningkatam hasil belajar antara hasil belajar Siklus I dengan kondisi Pra Siklus. Sebanyak 14 orang siswa dinyatakan tidak tuntas 
belajar karena memperoleh nilai di bawah Kriteria Ketuntasan Minimal (KKM) $(<79)$. Sedangkan yang tuntas sebanyak 8 orang siswa. Kemudian di siklus I 17 orang siswa tuntas dan 5 orang siswa belum tuntas. Dengan hasil ini, menunjukkan siswa mengalami peningkatan hasil belajar dalam menulis teks Report. Sedangkan pada Siklus II terjadi peningkatan hasil belajar siswa. Masih ada 4 orang siswa yang dinyatakan tidak tuntas karena memperoleh nilai di bawah Kriteria Ketuntasan Minimal (KKM) $(<79)$, dan sebanyak 18 orang siswa telah mencapai nilai ketuntasan.

Dominasi guru dalam pembelajaran dengan metode Mind Mapping menjadi berkurang, dan mengutamakan siswa terlibat aktif dalam pembelajaran. Untuk menuangkan ide dan gagasannya dengan menggunakan Mind Mapping.

Hasil refleksi menunjukkan, ternyata pembelajaran metode Mind Mapping menarik perhatian siswa dalam mengikuti pembelajaran Bahasa Inggris dan dalam menuangkan ide dan gagasannya dalam bentuk tulisan. Siswa terlihat serius mendengarkan guru dan siswa berkonsentrasi memahami materi yang diajarkan guru. Biasanya ada saja siswa yang tidak bersemangat ketika guru menerangkan, yang ditunjukkan oleh sikap siswa yang mengantuk, berbicara dengan temannya atau beralasan ke belakang. Perubahan hasil belajar siswa untuk belajar terlihat dari hasil nilai tes yang meningkat, walau masih ada yang di bawah Kriteria Ketuntasan Minimal (KKM) $(<78)$, tetapi dilihat dari perolehan nilai siswa tersebut meningkat dengan baik.

\section{KESIMPULAN}

Dengan mengetahui bahwa pemicu rendahnya kemampuan menulis teks Report pada siswa kelas IX E, semester I, SMP Negeri 2 Bebandem adalah faktor metode yang digunakan guru, sehingga penggantian metode yang kurang tepat sangat diperlukan, sehingga dengan penggunaan metode Mind Mappping dalam upaya untuk meningkatkan kemampuan menulis teks Report.

Berdasarkan pada rendahnya kemampuan siswa menulis teks Report yang disampaikan pada latar belakang masalah, penggunaan metode Mind Mapping dalam pembelajaran diupayakan untuk dapat menyelesaikan permasalahan dalam penelitian ini yaitu untuk meningkatkan kemampuan siswa dalam menulis teks Report. Seberapa besar peningkatan yang disampai sudah dipaparkan dengan jelas pada akhir analisis. Dari hasil penelitian yang disampaikan pada Bab IV dan semua data yang telah disampaikan terebut, tujuan penelitian yang disampaikan sudah dapat dicapai.

Untuk menjawab tujuan penelitain yaitu pencapaian peningkatan kemampuan menulis siswa dapat dilihat dari bukti-bukti yang sudah disiapkan.

a. Dari data pelaksanan Pra Siklus ada 16 orang siswa yang memperoleh nilai dibawah Kriteria Ketuntasan Minimal (KKM). Pada Siklus I menurun menjadi 5 orang siswa dan siklus II hanya 4 orang siswa mendapat nilai dibawah Kriteria Ketuntasan Minimal (KKM).

b. Dari data pelaksanan Pra Siklus nilai rata-rata 69,77 naik menjadi 78,63 pada pelaksanaan Siklus I dan pada pelaksanaan Siklus II naik menjadi 81,59.

c. Dari data pelaksanan Pra Siklus siswa yang tuntas hanya 6 orang siswa atau 36,36\%, sedangkan pada siklus I menjadi lebih banyak yaitu 17 orang siswa atau 77,27\% dan pada siklus II meningkat menjadi 18orang siswa atau 81,81\%.

Dari semua data pendukung pembuktian pencapaian tujuan pembelajaran dapat disimpulkan bahwa metode Mind Maping dapat meningkatkan kemampuan siswa dalam menulis teks Report.

\section{DAFTAR PUSTAKA}

Burhan Nurgiantoro. (1988). Penilaian Dalam Pengajaran Bahasa dan Sastra. Yogyakarta : BPFE

Buzan, Tony. (2012). Buku Pintar Mind Map. Jakarta: Gramedia 
Depdiknas. (2006). Bunga Rampai Keberhasilan Guru dalam Pembelajaran (SMA, SMK, dan $S L B)$. Jakarta: Depdiknas.

Deporter, Bobbi, dkk. (2010). Quantum Teaching. Bandung: Kaifa

Dimyati dan Mudjiono. (2009). Belajar dan Pembelajaran. Jakarta: PT Rineka Cipta.

Djamarah, Syaiful Bahri dan Aswan Zain. (2010). Strategi Belajar Mengajar. Jakarta: Rineka Cipta

Djago Tarigan, H.G. Tarigan. (1986). Teknik Pengajaran Keterampilan Berbahasa. Bandung: Penerbit Angkasa

Elina Syarif, Zulkarnaini, Sumarno. (2009). Pembelajaran Menulis. Jakarta: Departemen Pendidikan Nasional

Hamalik, Oemar. (2006). Proses Belajar Mengajar. Jakarta: PT Bumi Aksara

Imas Kurniasih dan Berlin Sani (2016) Ragam Pengembangan Model Pembelajaran untuk Peningkatan Profesionalitas Guru. Yogyakarta: Kata Pena.

Jumanto. (2010). Peningkatan Kemampuan Menulis Cerita Melalui Metode (Mind Mapping) pada Siswa Kelas IV SD Negeri Sondakan No. 11 Surakarta. Skripsi. Surakarta: Tidak Diterbitkan

Kemmis S dan R. Mc Taggart. (1992). The Action Research Planner. Victoria: Deakin University.

M. Atar Semi. (2007). Dasar-Dasar Keterampilan Menulis. Bandung: Angkasa

Ni Made Ratminingsih. (2017). Metode dan Strategi Pembelajaran Bahasa Inggris. Depok: PT Rajagrafindo Persada

Santrock, J. W. (2004). Educational psychology. Second edition. New York: McGraw Hill. 